\title{
Морковь и тыква мускатная на снеки
}

\section{П.Д. Осмоловский, А.В. Корнев, Н.Н. Воробьева, Н.А. Пискунова, С.Л. Игнатьева, Л.А. Неменущая}

Проведена оценка сортообразцов моркови столовой и тыквы мускатной и установлена их пригодность для получения натуральной высококачественной снековой продукции с высоким содержанием каротиноидов: $\beta$-каротин в готовом продукте сохранялся на 82,78-87,09\% у сортов тыквы и на 81,91\% у оранжевой моркови 690B, а лютеин - на 83,17\% у желтой моркови П1.

Ключевые слова: морковь столовая, тыква мускатная, сорт, снеки, каротиноиды.

$\mathrm{H}$ аучная основа современной стратегии производства продуктов питания - изыскание новых ресурсов, обеспечивающих оптимальные для организма уровни и соотношения химических компонентов. На прилавках российских магазинов стали появляться новые виды снеков. Все больше и больше потребителей выбирает «здоровые» снеки - натуральные, низкокалорийные, содержащие мало жиров и много витаминов, минеральных веществ и клетчатки [1], а современные технологии производства снековой продукции позволяют обеспечить потребителя безопасными продуктами питания, в том числе и за счет применения альтернативных видов сырья [2].

Достижения селекционной науки позволяют получать высокие урожаи весьма ценных в пищевом отношении корнеплодов моркови и плодов тыквы мускатной, характеризующихся повышенным содержанием каротиноидов от 22 мг\% [3] до 37,1 мг\% [4] в корнеплодах моркови и 27,5 мг\% в плодах тыквы мускатной [5]. Селекционная работа во ВНИИО - филиале ФГБНУ ФНЦО с морковью столовой разнообразной окраски в направлении создания новых высокоурожайных сортов и гетерозисных гибридов с высоким качеством корнеплодов [6] показала их ценность как источников каротиноидов, содержание которых обусловлено в первую очередь эколого-географическими условиями региона выращивания корнеплодов и сортиментом культуры [7].

Цель исследований - оценка сортообразцов моркови столовой и тыквы мускатной на пригодность к пере- работке для получения продуктов высокого качества.

Целесообразность использования плодов тыквы для производства кондированной продукции $[8,9]$ и корнеплодов моркови с различной окраской корнеплодов для изготовления снековой продукции высокого качества с прекрасными цветовыми характеристиками, позволяющими, в том числе, изготавливать привлекательные по цветовой гамме смеси [10], подтверждена проведенными ранее исследованиями. В продолжение этих исследований в 2018-2019 годах на базе ФГБОУ ВО РГАУ-МСХА имени К.А. Тимирязева, ВНИИО - филиала ФГБНУ ФНЦО и ООО «Селекционная станция имени Н.Н. Тимофеева» проводилась химико-технологическая оценка корнеплодов моркови (селекционный материал ФГБНУ ФНЦО: сорт Арго - белой окраски, образец П1 - желтой окраски и линия $690 \mathrm{~B}$ - оранжевой окраски) и плодов тыквы мускатной (селекционный материал ООО «Селекционная станция имени Н.Н. Тимофеева»: сорта Цукатная и Московская ароматная - с ярко оранжевой окраской мя- коти) на пригодность для получения натуральной высококачественной снековой продукции, в основе технологии производства которой лежит кондирование с последующим подсушиванием до влажности 10\% [10]. Органолептическая оценка (дегустация) готового продукта проводилась в соответствии с ГОСТ 8756.1-2017 [11].

Как показали результаты исследований (табл.), в свежем сырье моркови столовой и тыквы мускатной высокое содержание $\beta$-каротина было у сорта тыквы Московская ароматная $(9,88$ мг/100 г сырой массы) и линии моркови 690В (12,11 мг/100 г сырой массы) при сумме каротиноидов 11,86 и 13,12 мг/100 г сырой массы соответственно. Наибольшим содержанием лютеина отличались корнеплоды образца желтой моркови П1 (3,09 мг/100 г сырой массы), плоды тыквы сорта Московская ароматная (1,1 мг/100 г сырой массы). Плоды изученных сортов тыквы мускатной содержали в своем составе также и ликопин в количестве 0,48 (Цукатная) - 0,88 (Московская ароматная) мг/100 г сырой массы.

В процессе изготовления снековой продукции происходило снижение содержания каротиноидов на $12,91-35,42 \%$ в зависимости от вида сырья и вида биологически активного вещества, что, вероятно, связано с физико-химическими превращениями этих веществ при пропитывании сырья сахарным сиропом. Максимально сохранялся $\beta$-каротин в продукции, изготовленной из плодов тыквы сорта Цукатная (на 87,09\%) и корнеплодов моркови линии 690B (на 81,91\%), лютеин - в продукции, изготовленной из плодов тыквы сорта Цукатная (на 85,24\%) и корнеплодов образца желтой моркови П1 (на 83,17\%). В продукции, изготовленной из корнеплодов сорта белой моркови Арго, сумма каротинои-

Содержание каротиноидов в свежем сырье и готовой продукции моркови столовой и тыквы мускатной, мг/100 г сырой массы (2018-2019 годы)

\begin{tabular}{|c|c|c|c|c|c|c|}
\hline \multirow{2}{*}{$\begin{array}{c}\text { Сорт, } \\
\text { образец }\end{array}$} & \multicolumn{2}{|c|}{ Ликопин } & \multicolumn{2}{|c|}{$\beta$-каротин } & \multicolumn{2}{|c|}{ Лютеин } \\
\hline & сырье & снеки & сырье & снеки & сырье & снеки \\
\hline \multicolumn{7}{|c|}{ тыква мускатная } \\
\hline $\begin{array}{l}\text { Московская } \\
\text { ароматная }\end{array}$ & 0,88 & 0,70 & 9,88 & 8,12 & 1,10 & 0,82 \\
\hline Цукатная & 0,48 & 0,31 & 5,81 & 5,06 & 0,61 & 0,52 \\
\hline \multicolumn{7}{|c|}{ морковь столовая } \\
\hline Арго & \multirow{3}{*}{\multicolumn{2}{|c|}{ следы }} & 0,41 & 0,30 & 0,20 & 0,14 \\
\hline$\Pi 1$ & & & 1,21 & 1,02 & 3,09 & 2,57 \\
\hline $690 B$ & & & 12,11 & 9,92 & 1,01 & 0,69 \\
\hline
\end{tabular}




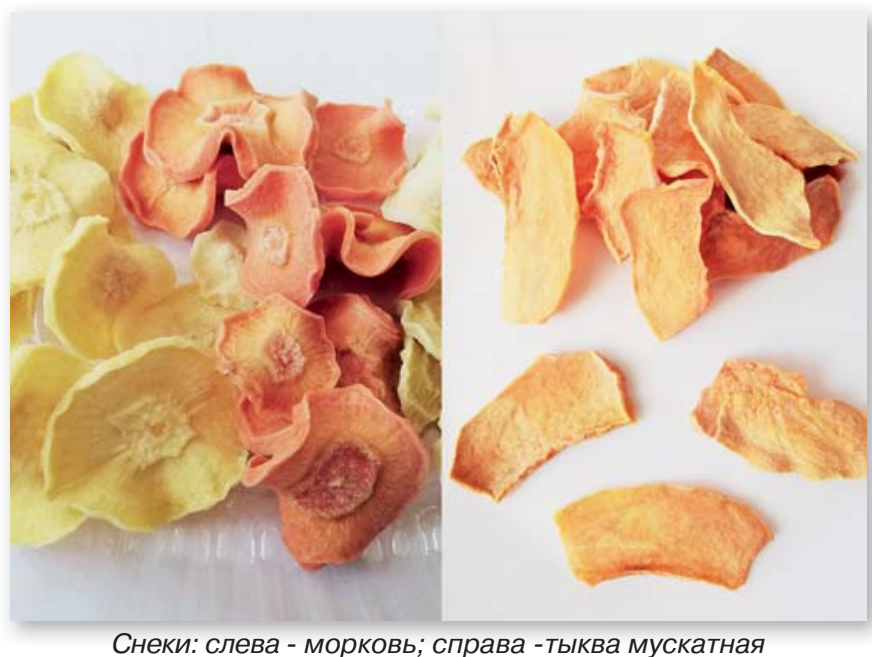

дов удерживалась на уровне 73,13\%. В конечном счете, готовая продукция содержала в своем составе каротиноиды в пределах от 0,44 (Арго) до 10,61 (690B) мг/100 г сырой массы, что составляет $73,13-85,36 \%$ от содержания каротиноидов в сырье.

Органолептическая оценка готового продукта показала, что из изученных образцов моркови столовой и тыквы мускатной можно получить снековую продукцию достаточно высокого качества (дегустационные оценки на уровне 4,31-4,44 балла). При этом продукция, изготовленная из корнеплодов линии оранжевой моркови 690В, выделялась по внешней привлекательности продукта $(4,45$ балла) и аромату (4,48 балла); продукция, изготовленная из корнеплодов образца желтой моркови П1 отличалась по вкусовым характеристикам (4,4 балла) и общей итоговой оценке $(4,44$ балла); продукция, изготовленная из плодов тыквы мускатной сорта Московская ароматная отмечена по цветовым характеристикам (4,6 балла) и консистенции продукта (4,5 балла).

Отметим, что у продукции, изготовленной из корнеплодов моркови столовой оранжевой окраски линии 690В и плодов тыквы мускатной сорта Московская ароматная (рис.), были привлекательный внешний вид и интенсивная ярко-оранжевая окраска, обусловленные в том числе и высоким содержанием $\beta$-каротина. К тому же эта продукция, была самой ароматной (690В) и имеющей приятную упругую и хрустящую консистенцию (Московская ароматная). Продукция же, изготовленная из корнеплодов желтой моркови (П1), выделялась по выравненности кусочков ввиду того, что корнеплоды были цилиндричес- кой формы, а также по вкусовым характеристикам.

Таким образом, изученные сортообразцы моркови столовой и тыквы мускатной могут служить сырьем для получения натуральной высококачествен ной снековой продукции, имеющей привлекательный внешний вид, яркую окраску и высокое содержание каротиноидов: $\beta$-каротин в готовом продукте сохранялся на 82,78-87,09\% у сортов тыквы и на $81,91 \%$ у оранжевой моркови 690В, а лютеин - на 83,17\% у желтой моркови П1.

\section{Библиографический список}

1.Савенкова Т.В. Снеки - продукты современного образа жизни // Бизнес пищевых ингредиентов. 2015. № 1 (46). С. 42-44.

2.Калинина И.В., Руськина А.А. Современные подходы в технологии безопасной снэковой продукции // Вестник ЮУрГУ. Серия «Пищевые и биотехнологии». 2014. № 3. T. 2. C. 29-36.

3.Корнев А.В. Оценка и создание исходного материала моркови столовой с разнообразной окраской корнеплода и повышенным содержанием биологически активных веществ ( $\beta$-каротина, лютеина, ликопина и антоцианов): автореф. дис... канд. с-х. наук. М., 2015. $31 \mathrm{c}$.

4.Борисов В.А., Литвинов С.С., Романова А.В. Качество и лежкость овощей. М., 2003. 625 с.

5.Акинделе Аденике Кехинде и др. Выращивание тыквы в Нечерноземной зоне РФ и ее использование для переработки // Вестник овощевода. 2011. № 5. С. 30-32.

6.Корнев А.В., Леунов В.И., Ховрин А.Н. Изменчивость отдельных признаков моркови столовой разнообразной окраски корнеплода // Овощи России. 2017. № 4 (37). C. 41-44.

7.Корнев А.В., Леунов В.И., Ховрин А.Н., Цимбалаев С.Р. Сравнительная характеристика сортов столовой моркови по содержанию каротиноидов и антоцианов // Хранение и переработка сельхозсырья. 2014. № 9. С. 48-50.

8.Байдулова Э.В., Воробьева Н.Н., Пискунова Н.А. Сорта и гибриды тыквы для кондитерской промышленности // Картофель и овощи. 2009. № 10. С. 12.

9.Акинделе Аденике Кехинде и др. Получение кондированной продукции из тыквы // Пищевая промышленность. 2011. № 8. С. 34-35.

10.Пискунова Н.А., Корнев А.В., Осмоловский П.Д., Игнатьева С.Л. Морковь столовая с разнообразной окраской корнеплодов для изготовления снековой продукции // Картофель и овощи. 2018. № 6. С. $38-40$

11.ГОСТ 8756.1-2017. Продукты переработки фруктов, овощей и грибов. Методы определения органолептических показателей, массовой доли составных частей, массы нетто или объема. М.: Стандартинформ, 2017. 12 c.

\section{Об авторах}

Осмоловский Павел Дмитриевич, аспирант кафедры технологии хране- ния и переработки плодов и овощей, ФГБОУ ВО РГАУ-МСХА именИ К.А.

Тимирязева.

E-mail: pavel.osmolovsku@mail.ru

Корнев Александр Владимирович, канд. с. - х. наук, н.с. отдела селекции и семеноводства, ВНИиО - филиал ФГБНУ ФНЦО.

E-mail: alexandrvg@gmail.com

\section{Воробьева Надежда Николаевна,} канд. с. - х. наук, с.н.с., ООО «Селекционная станция имени Н.H.

\section{Тимофеева»}

Пискунова Наталья Анатольевна, канд. с. - х. наук, профессор кафедры технологии хранения и переработкИ пЛОДОв и овощей, ФГБОУ ВО РГАУМСХА имени К.А. Тимирязева

Игнатьева Светлана Леонидовна, канд. с-х. наук, доцент кафедры экологии, ФГБОУ ВО РГАУ-МСХА имени К.А.Тимирязева.

E-mail: ignatevas@yandex.ru

Неменущая Людмила

Алексеевна, С.Н.С., ФГБНУ

«Росинформагротех».

E-mail: nela-21@mail.ru

Carrots and pumpkin for snacks making P.D. Osmolovskii, postgraduate student of the department of technology for storage and processing of fruits and vegetables, Russian State Agrarian University-MTAA named after K.A. Timiryazev (RSAU MTAA).E-mail: pavel.osmolovsku@mail.ru A.V. Kornev, PhD, research fellow of the department of breeding and seed growing, All-Russian Research Institute of Vegetable Growing - the branch of Federal Scientific Budgetary Institution Federal Scientific Centre of Vegetables (ARRIVG-branch of FSBSI FSVC).E-mail: alexandrvg@gmail.com N.N. Vorobeva, PhD, senior research fellow, LLC Selection station named after N.N. Timofeev

N.A. Piskunova, PhD, professor of department of technology of storage and processing of fruits and vegetables, RSAU - MTAA.

S.L. Ignatieva, $P h D$, associate professor of department of ecology, RSAU - MTAA.

E-mail: ignatevas@yandex.ru

L.A. Nemenushchaya, senior research fellow, Rosinformagrotech.

E-mail: nela-21@mail.ru

Summary. The evaluation of varieties of carrots and pumpkin has been carried out and their suitability for obtaining natural highquality snack products with a high content of carotenoids has been established.

Keywords: carrots, pumpkin, variety, snacks, carotenoids. 